\title{
The Haemoculture of Trypanosoma minasense Chagas, 1908
}

\section{Mariangela Ziccardi $/{ }^{+}$, Ricardo Lourenço-de-Oliveira, Ricardo Nogueira*}

\author{
Laboratório de Transmissores de Hematozoários, Departamento de Entomologia *Laboratório de Imunidade \\ Celular e Humoral, Departamento de Protozoologia, Instituto Oswaldo Cruz, Av. Brasil 4365, 21045-900 \\ Rio de Janeiro, RJ, Brasil
}

Trypanosoma minasense was isolated for the first time in blood axenic culture from a naturally infected marmoset, Callithrix penicillata, from Brazil. The parasite grew profusely in an overlay of Roswell Park Memorial Institute medium plus 20\% foetal bovine serum, on Novy, McNeal and Nicolle medium $(N N N)$, at $27^{\circ} \mathrm{C}$, with a peak around $168 \mathrm{hr}$.

The morphometry of cultural forms of $\mathrm{T}$. minasense, estimates of cell population size and comparative growth in four different media overlays always with NNN, were studied. The infectivity of cultural forms to marmosets (C. penicillata and C. jacchus) and transformation of epimastigotes into metacycliclike forms in axenic culture in the presence of chitin derivates (chitosan) were evaluated.

Key words: Trypanosoma minasense - neotropical primates - trypanosomes - marmosets trypanosomatidae flagellates - culture - Brazil

Trypomastigotes of Trypanosoma (Megatrypanum) minasense were originally described by Chagas (1908) in the blood of a marmoset, Callithrix penicillata, from Lassance, State of Minas Gerais (MG), southeastern Brazil. This trypanosome is a widely distributed species detected in 32 species or subspecies of neotropical non-human primates, principally small monkeys (Cebidae), marmosets and tamarins (Callithrichidae), from Panama to southeastern Brazil (Carini 1909, Cerqueira 1924, Dios et al. 1925, Deane \& Damasceno 1961, Dunn et al. 1963, Deane et al. 1974, Souza et al. 1974, Souza \& Dawson 1976, Deane 1979, Deane et al. 1989, Lourenço-de-Oliveira et al. 1991, Resende et al. 1994, Ziccardi et al. 1994, Deane, pers. commun.).

It is the only Trypanosoma in which circadian rhythm in the parasitaemia has been reported (Deane et al. 1974).

Infections with $T$. minasense are usually scanty, and division stages have never been detected in the simian host. It does not infect triatomine bugs and nothing is known about the vectors in nature. Attempts to infect laboratory rodents and dogs have also failed (Hoare 1972).

Rodhain (1937), Deane and Damasceno (1961) and Marinkelle (1966) were unable to cultivate this trypanosome in axenic culture media, such as Novy, McNeal and Nicolle (NNN), and previous attempts to cultivate this parasite from blood samples of marmosets and monkeys from several localities in southeastern and northern Brazil have

${ }^{+}$Corresponding author: Fax: 55-021-290.9339

Received 2 October 1995

Accepted 28 February 1996 also been unsuccessful (Lourenço-de-Oliviera, unpublished data).

This paper records the axenic culture of $T$. minasense in a modified "Roswell Park Memorial Institute - Novy, McNeal and Nicolle" (RPMINNN) medium.

\section{MATERIALS AND METHODS}

A specimen of the marmoset $C$. penicillata (No. 63), caught in Felixlândia (MG) in May 1991, was shown to be naturally infected with $T$. minasense following the examination of thick and thin blood smears. No other blood parasites were detected, and xenodiagnosis made with six nymphs of 3rd and 4th instar Rhodnius prolixus was negative. The parasite did not grow in blood-agar culture medium NNN/LIT .

A single further attempt at haemoculture was carried out using the same media (NNN + LIT), 17 months later when the marmoset still showed only $T$. minasense in its blood. The culture was poor on the seventh day and the parasites were subcultured into four different media, over NNN slopes: 1. Roswell Park Memorial Institute (RPMI 1640, Sigma) plus 10mM Hepes, $1.5 \mathrm{mM} / 1 \mathrm{~L} \mathrm{L-}$ glutamine, $20 \%$ of foetal bovine serum (FBS, Microbiológica), penicillin $200 \mathrm{UI} / \mathrm{ml}$ and streptomycin $200 \mu \mathrm{g} / \mathrm{ml} ; 2$. Liver Infusion Tryptose (LIT); 3. Schneider's Drosophila medium (Schneider 1966); and 4. Dulbecco's Modified Eagle's (DME, Sigma), all supplemented with $20 \%$ (FBS) and penicillin $200 \mathrm{UI} / \mathrm{ml}$.

The absence of $T$. cruzi and $T$. rangeli in the cultures was tested by the inoculation of $0.1 \mathrm{ml}$ of the culture $\left(10^{6}\right.$ parasites $\left./ \mathrm{ml}\right)$ into ten 10 days-old albino mice. Their blood were examined (fresh and Giemsa-stained smears) from 7 to 20 days after 
inoculation. Then, all the inoculated mice were sacrificed and haemoculture (NNN + LIT) was made and the cultures microscopically examined during one month.

In addition, we tried to infect 30 nymphs of 3 rd and 4 th instar $R$. prolixus by feeding them through a membrane (Garcia et al. 1984) on sterile defibrinated sheep blood mixed with the same culture. The search for parasites in the bugs was conducted 5, 13 and 25 days after the blood meal.

A one month old $C$. penicillata marmoset (No. 71), born and reared in the laboratory and negative for trypanosomes, was inoculated intraperitoneally (IP) and subcutaneously (SC) with $0.5 \mathrm{ml}$ of a 13 days-old sample (4th passage) of the original culture of $T$. minasense. The search for parasites in the marmoset was made by thin and thick Giemsa-stained blood smears from day 5 to day 30 post inoculation (p.i).

Two adult $C$. jacchus marmosets (No. 74 and 76) were injected (IP/SC) with $0.5 \mathrm{ml}$ of the $2 \mathrm{nd}$ passage of the original culture, previously cryopreserved for one month in liquid nitrogen. The animals were submitted to blood examination (thin and thick smears), xenodiagnosis (six nymphs of 3rd instar of $R$. prolixus) and haemoculture $(\mathrm{NNN}+\mathrm{LIT})$ for 30 days.

A third adult $C$. jacchus marmoset (No. 77), was inoculated intravenously (IV) with $0.5 \mathrm{ml}$ of the 2 nd subculture of the original isolation of the trypanosome, previously cryopreserved for eleven months, and diluted after quick centrifugation with sterile saline. The animal was examined (thick blood smears) from day 7 to day 120 p.i. Another attempt to infect the same animal was made by injecting it (IV) with material from subcultures, diluted in PBS pH 7.2. The marmoset was then examined from the day 7 to day 15 p.i.

We have tried to stimulate the transformation of $T$. minasense epimastigotes into metacyclic-like trypomastigotes in axenic culture, using chitin derivates (chitosan) according to the method of Wallbanks et al. (1989), using three concentrations: $150,300,600 \mathrm{mg}$ of chitosan/5 ml of RPMI. Parasites were sampled at roughly $24 \mathrm{hr}$ periods, when fresh medium (RPMI) was replaced.

The estimates of cell population size were made by a direct count in a haemocytometer (Neubauer).

\section{RESULTS}

NNN medium overlaid with RPMI gave the best growth-rate of $T$. minasense (Table I).

The blood of all mice inoculated with $T$. minasense culture, their respective haemocultures and xenodiagnoses (gut contents and faeces) were negative. Based on these experiments we concluded that the culture was free from both $T$. rangeli and $T$. cruzi, and composed purely of T. minasense.

The epimastigotes and trypomastigotes found in the culture were quite distinct. Fig. 1 and Table

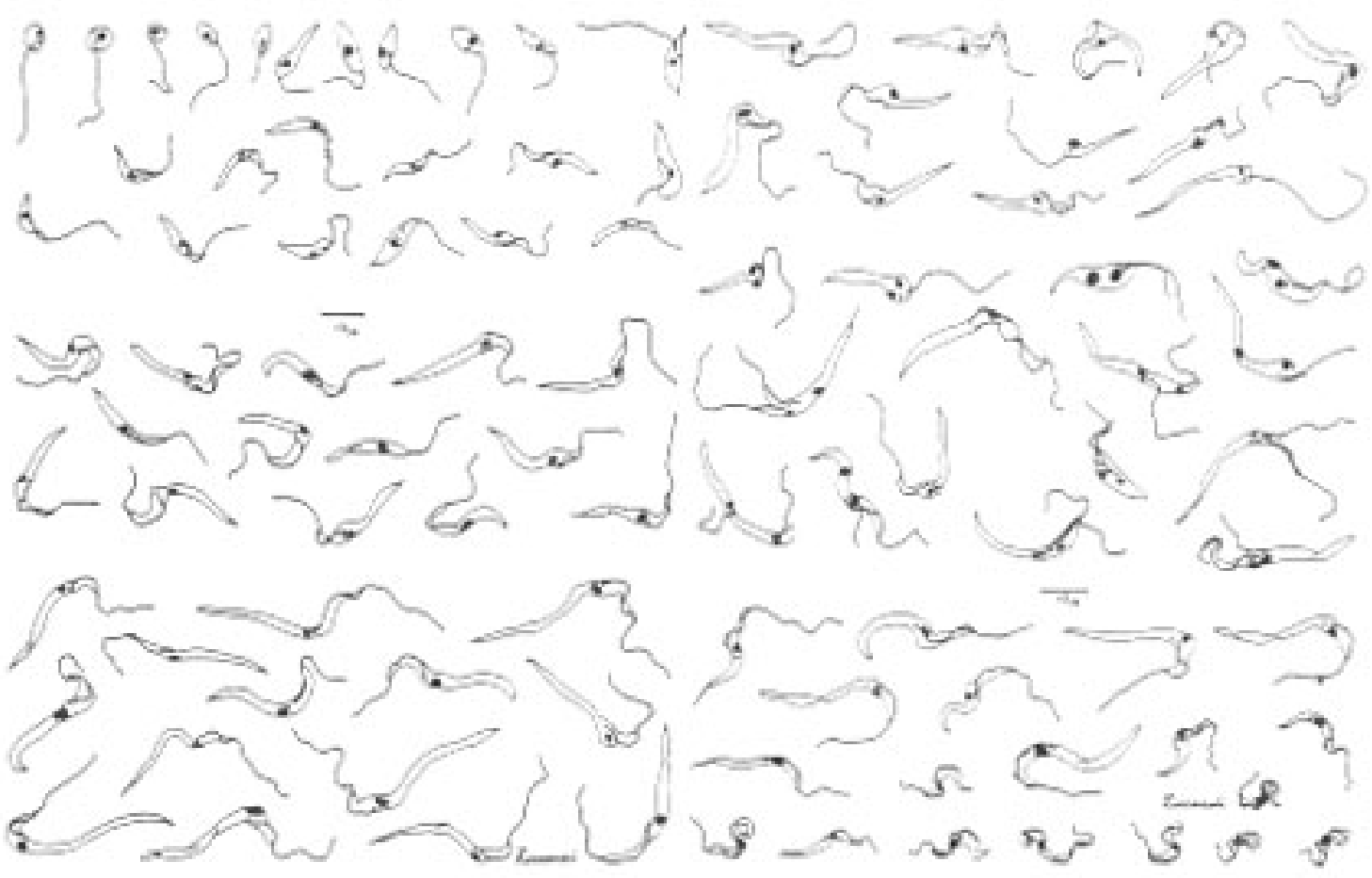

Fig. 1: Trypanosoma minasense. Forms found in haemoculture (NNN+RPMI) from a naturally infected Callithrix penicillata marmoset (No. 63) caught in Felixlândia (MG), Brazil. 


\section{TABLE I}

Comparative scores ${ }^{a}$ of cultural forms of Trypanosoma minasense in different media after 3, 6 and 12 days of culture

\begin{tabular}{lccc}
\hline Culture media $^{b}$ & \multicolumn{3}{c}{ Days of culture } \\
\cline { 2 - 4 } & 3 & 6 & 12 \\
\hline NNN & $1 \times 10^{2}$ & $1.2 \times 10^{5}$ & 0 \\
NNN+Dulbecco's & 0 & 0 & 0 \\
NNN+LIT & $1 \times 10^{3}$ & $7.5 \times 10^{4}$ & 0 \\
NNN+RPMI & $1 \times 10^{4}$ & $1.5 \times 10^{5}$ & $1 \times 10^{6}$ \\
NNN+Schneider's & $1 \times 10^{2}$ & 0 & 0
\end{tabular}

$a$ : number expressed in parasites $/ \mathrm{ml} ; b$ : all media supplemented with $20 \%$ (FBS) and incubated at $27^{\circ} \mathrm{C}$; media: NNN (Novy, McNeal and Nicolle); LIT (Liver Infusion Tryptose); RPMI (Roswell Park Memorial Institute)

II show, respectively, camera-lucida drawings and the measurements of the most commonly detected cultural forms. We observed a great variety of forms in the culture of $T$. minasense, as follows: round epimastigotes with a long, free flagellum; short, long and slender epimastigotes; and large epimastigotes reaching up to $70.0 \mu \mathrm{m}$ in length and $4.5 \mu \mathrm{m}$ in width. Stout epimastigotes, sometimes provided with a free flagellum of up to $42.0 \mu \mathrm{m}$ long were also seen; epimastigotes in binary fission; and long and short trypomastigotes, some of which appeared to be metacyclic forms.

The injected $C$. penicillata (No. 71) marmoset became infected, presenting the following parasitaemia (parasites/thick blood smear of $5 \mu \mathrm{l}$, according to Earle \& Perez 1932): 5th day, 2 forms; 7th day, 18; 12th day, 28; 19th day, 18 and 21st day, 7 . The blood stream parasites found in the 5 th day were little thinner than the typical $T$. minasense trypomastigotes seen later on the 7 th day. The peak of parasitaemia was on the 12th day after inoculation. No division stages were seen.

The three inoculated $C$. jacchus (No. 74, 76, 77) failed to become infected.

In NNN + RPMI, the isolate of $T$. minasense presented a maximum growth at $168 \mathrm{hr}$, with about $8.9 \times 10^{6}$ parasites $/ \mathrm{ml}$ (Fig. 2).

The percentage of metacyclic-like forms detected in the cultures with added chitosan were periodically evaluated. The highest number of trypomastigotes was recorded after the first change of media, with $300 \mathrm{mg}$ of chitosan/5 ml of RPMI (Table III).

\section{DISCUSSION}

Hoare (1972) regarded the species belonging to subgenus Megatrypanum as phylogenetically the most primitive representatives of the genus Trypanosoma of mammals. At least three species of Megatrypanum, have been found in New World monkeys and marmosets: $T$. (M.) minasense, $T$. (M.) devei and T. (M.) lambretchi. They are, so far, not known to infect man.

T. lambretchi is easily cultured in Tobie's blood-agar diphasic medium, with either human or rabbit blood, although development is slow (Lambrecht 1965, Marinkelle 1968). Pro-

\section{TABLE II}

Morphometric analysis of flagellates found in the axenic culture of Trypanosoma minasense (NNN+RPMI) isolated from Callithrix penicillata. Ranges given with means in parentheses

\begin{tabular}{|c|c|c|c|c|c|c|c|}
\hline Forms & $\begin{array}{c}\text { No. } \\
\text { neasured }\end{array}$ & $\mathrm{L}$ & PK & $\mathrm{KN}$ & NA & $\mathrm{F}$ & B \\
\hline Short epimastigotes & 23 & $\begin{array}{c}13.0-43.0 \\
(29.2)\end{array}$ & $\begin{array}{c}0.9-14.0 \\
(9.4)\end{array}$ & $\begin{array}{c}0.8-1.3 \\
(1.1)\end{array}$ & $\begin{array}{c}2.6-12.0 \\
(6.1)\end{array}$ & $\begin{array}{c}8.0-28.0 \\
(14.1)\end{array}$ & $\begin{array}{c}2.0-6.0 \\
(3.5)\end{array}$ \\
\hline Intermediate epimastigotes & 20 & $\begin{array}{c}34.0-52.0 \\
(45.0)\end{array}$ & $\begin{array}{c}9.0-22.0 \\
(16.8)\end{array}$ & $\begin{array}{c}0.4-2.0 \\
(1.0)\end{array}$ & $\begin{array}{c}8.0-14.0 \\
(10.5)\end{array}$ & $\begin{array}{c}7.0-26.0 \\
(14.2)\end{array}$ & $\begin{array}{c}2.0-4.0 \\
(3.9)\end{array}$ \\
\hline Long epimastigotes & 24 & $\begin{array}{c}41.0-70.0 \\
(54.4)\end{array}$ & $\begin{array}{c}7.0-35.0 \\
(23.4)\end{array}$ & $\begin{array}{c}0.4-3.0 \\
(1.4)\end{array}$ & $\begin{array}{c}5.0-27.0 \\
(11.8)\end{array}$ & $\begin{array}{c}10.0-21.0 \\
(17.0)\end{array}$ & $\begin{array}{c}1.9-4.5 \\
(2.8)\end{array}$ \\
\hline Stout epimastigotes & 11 & $\begin{array}{c}39.0-74.0 \\
(48.5)\end{array}$ & $\begin{array}{c}15.0-39.0 \\
(19.8)\end{array}$ & $\begin{array}{c}0.4-0.9 \\
(0.7)\end{array}$ & $\begin{array}{c}1.5-19.0 \\
(9.7)\end{array}$ & $\begin{array}{c}9.0-42.0 \\
(19.2)\end{array}$ & $\begin{array}{c}1.9-6.0 \\
(4.1)\end{array}$ \\
\hline Epimastigotes in binary fission & n 11 & $\begin{array}{c}30.0-65.0 \\
(48.8)\end{array}$ & $\begin{array}{c}16.0-31.0 \\
(22.5)\end{array}$ & $\begin{array}{c}0.2-11.0 \\
\quad(3.6)\end{array}$ & $\begin{array}{c}3.4-20.0 \\
(11.5)\end{array}$ & $\begin{array}{c}5.0-30.0 \\
(17.7)\end{array}$ & $\begin{array}{c}1.8-5.6 \\
(2.8)\end{array}$ \\
\hline Trypomastigotes & 18 & $\begin{array}{c}20.0-53.0 \\
(30.3)\end{array}$ & $\begin{array}{c}4.0-20.0 \\
(8.8)\end{array}$ & $\begin{array}{c}1.5-7.0 \\
(4.3)\end{array}$ & $\begin{array}{c}4.0-17.0 \\
(8.3)\end{array}$ & $\begin{array}{c}5.0-24.0 \\
(8.2)\end{array}$ & $\begin{array}{c}1.0-2.8 \\
(2.0)\end{array}$ \\
\hline
\end{tabular}

L: total length (including flagellum), PK: distance from posterior end of body to kinetoplast, KN: distance from kinetoplast to nucleus, NA: distance from nucleus to anterior end of body, F: length of the free flagellum, B: body with (at nucleus level); NNN (Novy, McNeal and Nicolle); RPMI (Roswell Park Memorial Institute) 


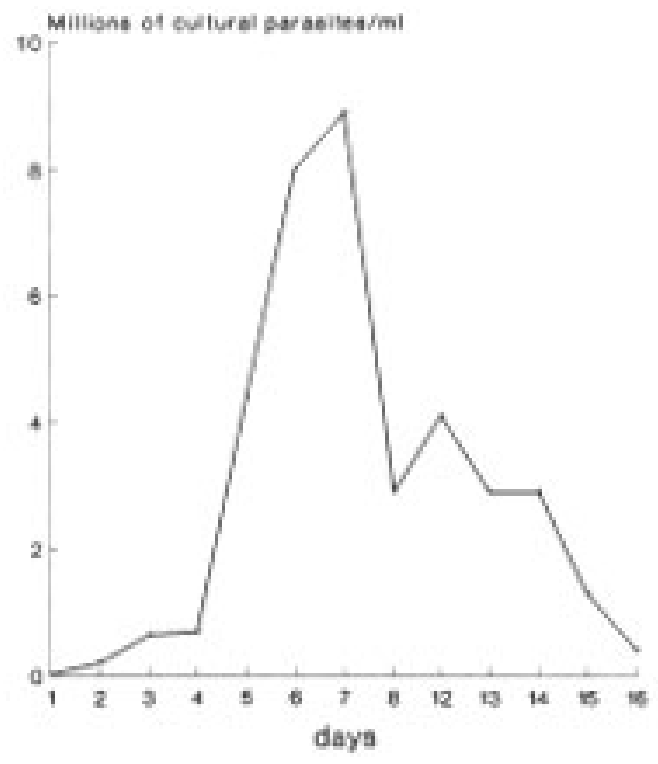

Fig. 2: estimates of cell population size in Trypanosoma minasense culture (NNN+RPMI).

mastigotes, usually in clusters, were the stages most commonly found, but short, stumpy, slowly-moving epimastigotes and occasional trypomastigotes were also detected in $T$. lambretchi cultures (Marinkelle 1976). According to Marinkelle (1976), there have been no previous reports on the multiplication in vivo or in vitro of any other trypanosome belonging to the subgenus Megatrypanum of neotropical non-human primates.

However, a strain of $T$. devei, from the tamarin Saguinus midas niger, was cultivated by Lanham et al. (1984) in blood-agar medium. The trypanosome grew profusely as long slender epimastigotes.

This is the first description of $T$. minasense multiplying in axenic culture, and the description and illustration of the cultural forms presented here now allows a better characterization of this parasite outside the vertebrate host, as well as a comparison with, and differentiation from other Megatrypanum species, such as $T$. devei and $T$. lambretchi, as described by Marinkelle (1976) and Lanham et al. (1984), and other New World trypanosomes such as $T$. cruzi and $T$. rangeli (viz. Hoare 1972).

The culture of $T$. minasense also now permits biochemical analysis using SDS-PAGE (sodium dodecyl sulfate-polyacrylamide gel electrophoresis) on a discontinuous SDS buffer system, in which the parasite has a quite distinct peptideme from $T$. rangeli, $T$. saimrii-like, $T$. cruzi and $T$. conorhini (Ziccardi 1995).

\section{TABLE III}

Percentage of metacyclic-like trypomastigotes of Trypanosoma minasense in culture (NNN+RPMI) in different concentrations of Crab Shell Chitosan (Sigma) were added

\begin{tabular}{|c|c|c|c|}
\hline \multirow{2}{*}{$\begin{array}{c}\text { Time of culture } \\
\text { (hours) }\end{array}$} & \multicolumn{3}{|c|}{ Concentration of chitosan ${ }^{a}$} \\
\hline & 150 & 300 & 600 \\
\hline 24 & --- & --- & $2 \%$ \\
\hline 48 & --- & 0 & $1 \%$ \\
\hline 72 & $14 \%$ & --- & --- \\
\hline 144 & $14 \%$ & 0 & 0 \\
\hline \multicolumn{4}{|c|}{$\left(1\right.$ st change of medium $\left.{ }^{b}\right)$} \\
\hline 72 & $5 \%$ & $4 \%$ & $6 \%$ \\
\hline 144 & $6 \%$ & $19.6 \%$ & $8.4 \%$ \\
\hline 240 & $\mathrm{c}$ & 0 & 0 \\
\hline \multicolumn{4}{|c|}{ (2nd change of medium ${ }^{b}$ ) } \\
\hline 56 & $\mathrm{c}$ & 0 & 0 \\
\hline 144 & $\mathrm{c}$ & 0 & 0 \\
\hline 168 & $\mathrm{c}$ & 0 & 0 \\
\hline \multicolumn{4}{|c|}{$\left(3 \mathrm{rd}\right.$ change of medium ${ }^{b}$ ) } \\
\hline 56 & $\mathrm{c}$ & 0 & 0 \\
\hline 104 & $\mathrm{c}$ & 0 & 0 \\
\hline 128 & $\mathrm{c}$ & 0 & 0 \\
\hline
\end{tabular}

$a$ : mg of chitosan $/ 5 \mathrm{ml}$ of RPMI; $b$ : RPMI, $20 \%$ FBS, $10 \mathrm{mM}$ Hepes, $1.5 \mathrm{nM} / 1 \mathrm{~L}$ L-glutamine, penicillin 200 $\mathrm{UI} / \mathrm{ml}$ and streptomycin $200 \mu \mathrm{g} / \mathrm{ml}$; c: contamination, scores disregarded; ---: not examined; media: NNN (Novy, McNeal and and Nicolle); RPMI (Roswell Park Memorial Institute)

Recently, we have failed to isolate $T$. minasense from two adult $C$. penicillata marmosets from Minas Gerais, using blood culture in four tubes with NNN + RPMI supplemented with $20 \%$ FBS. Its seems that the isolation and maintenance of $T$. minasense in these media is somewhat inconsistent and may depend on the phase of the infection at the time the culture is made. The haemoculture of $T$. minasense from the $C$. penicillata marmoset No. 63, for instance, was positive only in a second attempt made 17 months after the first negative one.

Actually, we have made several previous attempts to cultivate $T$. minasense from blood samples of infected marmosets from Minas Gerais (C. penicillata) and Rio de Janeiro (C. jacchus), in NNN blood-agar (Miles et al. 1980) and in NNN with overlay of LIT, brain heart infusion (BHI, Difco), RPMI and Schneider's. These either gave negative results or the culture was not successfully maintained. Other attempts with VERO cells with nutrient media such as LIT, RPMI or FBS have also been made. The longest maintenance of $T$. minasense in all these media (76 days) was obtained when the haemoculture was started in NNN + LIT and the flagellates later seeded in BHI, RPMI or Schneider's medium (Lourenço-de-Oliveira, unpublished data). 


\section{ACKNOWLEDGMENTS}

To Márcia G Castro and R Heyden for the help in the haemocultures and Teresa F Silva for the aid with the illustrations. To Alan Melo (UFMG) for blood samples of $C$. penicillata marmosets.

\section{REFERENCES}

Carini A 1909. Uber Trypanosoma minasense. Arch $f$ Schiffs Tropenhyg 13: 447-448.

Cerqueira D 1924. Trypanosoma minasense. Sciencia Médica 2: 155.

Chagas C 1908. Trypanosoma minasense. Brazil-Médico 22: 471 .

Deane LM 1979. Trypanosoma cruzi and other trypanosomes in Brasilian primates. p. D9. Anais do Congr. Inter. sobre D. de Chagas, Rio de Janeiro.

Deane LM, Damasceno RG 1961. Tripanosomídeos de mamíferos da região amazônica II. Tripanosomas de macacos da Zona do Salgado, Estado do Pará. Rev Inst Med Trop S Paulo 3: 61-70.

Deane LM, Lourenço-de-Oliveira R, Ziccardi MCB, Luz SLB 1989. Simian plasmodia and trypanosomes in Rondônia State, Brazil. Mem Inst Oswaldo Cruz 84 (Supl. II): 143.

Deane LM, Silva JE, Loures LF 1974. Nycthemeral variation in the parasitaemia of Trypanosoma minasense in naturally infected marmosets of the genus Callithrix (Primates, Callithricidae). Rev Inst Med Trop S Paulo 16: 1-6.

Dios RL, Zuccarini JA, Werngren ET 1925. Sobre la existencia de Trypanosoma minasense y Microfilaria sp. en monos. Rev Inst Bact 4: 176.

Dunn FL, Lambrecht FL, Du Plessis R 1963. Trypanosomes of South American monkeys and marmosets. Amer J Trop Med Hyg 12: 524-534.

Earle WC, Perez M 1932. Enumeration of parasites in the blood of malarial patients. J Lab Clin Med 17: 1124-1130.

Garcia ES, Azambuja P, Contreras VT 1984. Large-scale rearing of Rhodnius prolixus and production of metacyclic trypomastigotes of Trypanosoma cruzi, p. 44-47. In CM Morel, Genes and antigens of parasites. A laboratory manual, Fundação Oswaldo Cruz, Rio de Janeiro.

Hoare CA 1972. The trypanosomes of mammals. Blackwell Scientific Publication, Oxford, 749pp.

Lanham SM, Miles MA, Souza AAA, Póvoa MM 1984. Anion-exchange separation for neotropical trypanosomes: a preliminary trial and a description of Trypanosoma devei from the tamarin Saguinus midas niger. Z Parasitenkd 70: 311-319.
Lambrecht FL 1965. An unusual trypanosome in Cebus griseus F. Cuvier, 1819, from Colombia, South America. Rev Inst Med Trop S Paulo 7: 89-98.

Lourenço-de-Oliveira R, Ziccardi M, Luz SLB 1991. Additional notes on the trypanosomes in non human primates from Balbina, Amazonas state, Brazil. Mem Inst Oswaldo Cruz 86 (Suppl. I): 140.

Marinkelle CJ 1966. Observations on human, monkey and bat trypanosomes and their vectors in Colombia. Trans R Soc Trop Med Hyg 60: 109-116.

Marinkelle CJ 1968. Trypanosoma lambrechti n. sp. aislado de micos (Cebus albifrons) de Colombia. Caldasia 10: 155-164.

Marinkelle CJ 1976. The biology of the trypanosomes of non-human primates. p. 217-256. The biology of kinetoplastida, New York, Academic Press.

Miles MA, Lanham SM, Souza AA, Póvoa M 1980. Further enzymic characters of Trypanosoma cruzi and their evaluation for strain identification. Trans $R$ Soc Trop Med Hyg 74: 221-237.

Resende DM, Pereira LH, Lôbo A 1994. Long-term patency of blood parasitism by Trypanosoma minasense and Microfilariae in Callithrix penicillata Marmosets (Primates, Callitrichidae), caught in wild and maintained in captivity. Mem Inst Oswaldo Cruz, 89: $127-128$.

Rodhain J 1937. Notes sur Trypanosoma minasense Chagas. C R Soc Bio 125: 1034-1036.

Schneider I 1966. Histology of larval eye-antennal disks and cephalic ganglia of Drosophila cultured in vitro. J Embryol Expl Morphol 15: 271-279.

Souza OE, Dawson GA 1976. Trypanosome infections in the marmosets (Saguinus geoffroyi) from the Panama Canal Zone. Am J Trop Med Hyg 25: 407409.

Souza OE, Rossan N, Berg DC 1974. The prevalence of trypanosome and microfilaria in Panamanian monkeys. Am J Trop Med Hyg 23: 862-868.

Wallbanks KR, Molyneux DH, Dirie MF 1989. Chitin derivatives as novel substrates for Trypanosoma brucei brucei attachment in vitro. Acta Tropica 46: 63-68.

Ziccardi M 1995. Tripanosomas de macacos-de-cheiro: O que é o Trypanosoma saimirii Rodhain, 1941? MSc. Thesis. Instituto Oswaldo Cruz, Rio de Janeiro, 100pp.

Ziccardi M, Moreira GV, Pissinatti A, Lourenço-deOliveira R 1994. Trypanosoma cruzi and Trypanosoma minasense in lion tamarins (Primates: Callithrichidae). Mem Inst Oswaldo Cruz 89 (Suppl. I): 55. 
Haemoculture of T. minasense - M Ziccardi et al. 